\title{
Culminating Experiences: A National Survey of Accredited Institutions
}

\author{
Elizabeth Bjerke \\ University of North Dakota
}

\begin{abstract}
During the summer of 2007 the Aviation Accreditation Board International (AABI) approved a new set of criteria to be used in accrediting aviation degree programs. One addition to the new criteria is the inclusion of creating a culminating experience for all aviation program options. The purpose of this study was to discover the importance placed on incorporating a culminating experience in the aviation program curriculum, and to determine which of the general outcomes were being assessed. The results of the survey $(\mathrm{N}=55)$ indicate that all programs felt the culminating experience was an important part of their degree program. However, there was a variance in the number of outcomes assessed and the appropriateness to assess each outcome.
\end{abstract}

\section{INTRODUCTION}

In July of 2007, the Aviation Accreditation Board International's (AABI) Board of Trustees approved the new criteria based accreditation manual (AABI, n.d.). The new outcomes-based criteria replaced an older standards based approach to accrediting institutions of higher education. Outcomes based criteria places a greater emphasis and accountability on student learning, rather than focusing on curricular inputs.

AABI is a specialized accreditor that focuses on collegiate aviation education for both two-year and four-year, non-engineering related aviation programs. Specialized accreditation is not mandatory for institutions offering aviation education; in fact only $26 \%$ of University Aviation Administration's member institutions have AABI accredited programs (Prather, 2008). When seeking aviation accreditation there are six program options available: Aviation Management, Aviation Maintenance, Aviation Electronics, Aviation Studies, Flight Education, and Safety Science.

One significant change in the new AABI Criteria Manual is the inclusion of a culminating experience requirement for all program options falling under the baccalaureate criteria. The AABI (2009) culminating experience criterion is as follows:

Each program MUST provide evidence of a significant culminating upper division experience in (AABI Program Option). Examples of a culminating experience include a capstone course, an internship, or a special project that builds on prior course work. Evidence may include student portfolios and other records of student achievement. (p. 19) Prior to the new criteria, only the Aviation Management option required a culminating experience.

Another addition in the new criteria included 10 general outcomes for which graduates of accredited aviation programs must demonstrate either ability or knowledge. The AABI general outcomes are often referred to as 'outcomes a-j', thus the remainder of this article will post the corresponding letter to the outcome. Refer to Table 1 for a listing of the AABI approved general outcomes at the time of this study.

The purpose of this study was to discover what types of culminating experiences aviation programs were incorporating into their curriculum, and to determine which of the general outcomes were being analyzed, and how student learning was being assessed.

\section{REVIEW OF THE LITERATURE}

A culminating experience, or capstone course, is an ideal part of the curriculum that allows students to demonstrate mastery of the knowledge and skills acquired during their educational journey. It can also serve as a tool for assessing program learning outcomes, as well as aiding faculty in conducting overall program evaluations of existing curriculum. Although culminating experience outcomes tend to be similar across fields of study, the approach taken may differ. 
Table 1. General Outcomes

\begin{tabular}{l}
\hline AABI General Outcomes \\
\hline a. An ability to apply knowledge of mathematics, science, and applied sciences \\
b. An ability to analyze and interpret data \\
c. An ability to function on multi-disciplinary teams \\
d. An understanding of professional and ethical responsibility \\
e. An ability to communicate effectively, including both written and verbal communication skills \\
f. A recognition of the need for, and an ability to engage in, life-long learning \\
g. A knowledge of contemporary issues \\
h. An ability to use the techniques, skills, and modern technology necessary for \\
i. An understanding of the national and international aviation environment \\
j. An ability to apply pertinent knowledge in identifying and solving problems.
\end{tabular}

Note. From “Accreditation Criteria Manual”, by Aviation Accreditation Board International, 2008, Form 201, p. 7.

Strategic Management or Business Policy is a typical capstone course for a business management degree program (Parente, Brown, \& Warner, 2005). Due to the large number of accredited business programs there is an extensive amount of literature focusing on the implementation and forms of assessment of business capstone courses. Payne, Whitfield and Flynn (2002) propose a four phase approach to assessing business capstone courses combining the scholarship of teaching and learning with stakeholder theory. The four phases articulated were as follows: 1.) explore perspectives and practices elsewhere, 2.) examine institutional faculty perceptions and curricular concerns, 3.) discover student perceptions, and 4.) explore business community stakeholders. A more traditional approach to assessing student learning in a business capstone course is through competency based testing (Parente et al., 2005). Yet in another study (Payne, Flynn, \& Whitfield, 2008) student's were interviewed when entering a capstone course in order to assess their degree of motivation. This approach aided faculty in developing and changing the course to fulfill the perceived needs of the students.

While the field of business management education tends to favor a capstone course approach to the culminating experience, the discipline of engineering employs a senior design project as its culminating experience. Many of these senior design courses work closely with industry to solve real world problems (Todd \& Magleby, 2005; Jenkins,
Pocock, Zuraski, Meade, Mitchell \& Farrington, 2002; Padmanabhan \& Katti, 2002). In a synthesis of research conducted after the initial Accreditation Board for Engineering and Technology (ABET) criteria change in requiring a 'senior-level design course', it was found that although a proliferation of new courses were created to meet the accreditation requirement, the format tended to vary greatly between programs (Dutson, Todd, Magleby \& Sorensen, 1997). In a follow up study, Howe and Wilbarger (2005) surveyed ABET accredited institutions and found similar differences in formatting nearly a decade later. The survey also revealed a stronger trend towards industry involvement.

McKenzie, Trevisan, Davis and Beyerlein (2004) conducted a national survey of ABET accredited institutions regarding their use of the 'senior-level design course' in assessing the ABET general outcomes (a-k). It was found that $92 \%$ of the respondents felt that the capstone course played an important role in the overall educational experience of the students. The study also broke down the role in which the culminating experience played in the evaluation of each general outcome. Due to the likeness and similarities between the ABET general outcomes and the newly approved AABI general outcomes, permission to revise and use this survey tool for aviation education was obtained from the lead author. The survey tool was used to assist in answering the following research questions: 
1.) What percentage of aviation programs have a defined culminating experience in their curriculum?

2.) How important is the culminating experience in the aviation program?

3.) Which AABI general outcomes are considered appropriate to assess in a culminating experience, and which AABI general outcomes are being assessed in the culminating experience?

\section{METHODOLOGY}

\section{Participants}

During the fall of 2008 a survey was administered to all four-year AABI accredited institutions. A current listing of accredited programs was obtained from AABI. Only currently accredited programs were chosen for this study in order to better assess the implementation of the new outcomes-based criteria. At the time of this study there were 25 baccalaureate institutions consisting of 79 accredited programs. However due to the timeframe, no schools were yet accredited under the new criteria.

\section{Materials}

The survey tool used was adapted, with permission, from a similar study conducted for engineering education (McKenzie et al., 2004). Due to the similarity between the ABET and the AABI criteria, the survey tool was easily adapted for aviation education.

By replicating a previously conducted national study (McKenzie et al., 2004), many concerns of validity and reliability were addressed. However, the survey tool was also piloted by the Outcomes Resource and Training committee of AABI. This committee was made up of educators and industry representatives tasked with assisting AABI members during the transition to an outcomes-based accreditation.

A sample of the survey tool used is found in the appendix of this article.

\section{Procedures}

A survey packet was sent out via first class mail to 23 accredited institutions which are located in the United States. An identical packet was sent electronically to the two internationally accredited programs. The packet consisted of the following items: cover letter from researcher, support letter from AABI, separate survey questionnaire for each aviation accredited program at the institution and a self addressed stamp envelope for return purposes. For example, if an institution had three different aviation accredited programs such as Aviation Management, Flight Education and Aviation Studies, it would receive three separate survey tools to fill out. The rationale behind this method is that these are three different programs which may all have different culminating experiences defined.

The completed surveys were imported into both Microsoft Excel and SPSS version 16.0 for data analysis. In order to answer the stated research questions, both descriptive and inferential statistics were used. The following section states the results.

\section{FINDINGS}

Of the 25 institutions holding AABI accredited status, 16 (64\%) responded to this survey. More importantly, since the data was analyzed at the program level, of the 79 different accredited programs surveyed, 55 (70\%) responded. Table 2 lists the program options which responded to the survey.

Table 2. Program Options

\begin{tabular}{lll}
\hline Program Option & Number Responded & Percentage of Overall Responses \\
\hline Aviation Management & 18 & $35.3 \%$ \\
Flight Education & 15 & $29.4 \%$ \\
Aviation Studies & 11 & $21.6 \%$ \\
Aviation Maintenance & 4 & $7.8 \%$ \\
Aviation Electronics & 3 & $5.9 \%$ \\
\hline
\end{tabular}


Numerous Analysis of Variances (ANOVAs) were run between the program options and different variables on the survey with no significant differences being found. Thus the rest of the data analysis uses the entire data set together, and does not distinguish between program options.

Of the programs surveyed, $86.3 \%$ already had a culminating experience defined in their curriculum. The majority of the programs (60.8\%) are utilizing a capstone course, while another $19.6 \%$ are using a combination of methods to fulfill the requirement such as various courses or an internship experience. The vast majority $(82.4 \%)$ of the programs are conducting the culminating experience within one semester.

When asked of the importance that the culminating experience has on the institutions overall program all programs answered with either an important or very important response.
The mean of the response on a five point scale was 4.75 , with 5 indicating the highest level of importance.

In order to fully understand the role of the AABI general outcomes in the culminating experiences defined by each program, a series of questions were asked. First the respondents were asked which general outcomes they considered were appropriate to assess in the course. The mean numbers of outcomes considered appropriate to assess for the programs was 6.88 with a standard deviation of 2.18. Next the respondents were asked to identify which of the general outcomes they will assess in their culminating experience. The mean of the number of outcomes in which they will assess was 6.45 with a standard deviation of 2.27. Table 3 lists the results in order of greatest percentage to least percentage of assessments, and Figure 1 gives a graphical representation.

Table 3: General Outcomes and Assessment $(\mathrm{N}=55)$

\begin{tabular}{|l|c|c|}
\hline \multicolumn{1}{|c|}{ AABI General Outcome } & $\begin{array}{c}\text { Appropriate to Assess in } \\
\text { Culminating Experience }\end{array}$ & $\begin{array}{c}\text { Will Assess in } \\
\text { Culminating Experience }\end{array}$ \\
\hline $\begin{array}{l}\text { j. An ability to apply pertinent knowledge in } \\
\text { identifying and solving problems. }\end{array}$ & $96 \%$ & $96 \%$ \\
\hline b. An ability to analyze and interpret data & $94 \%$ & $94 \%$ \\
\hline $\begin{array}{l}\text { e. An ability to communicate effectively, including } \\
\text { both written and verbal communication skills }\end{array}$ & $84 \%$ & $76 \%$ \\
\hline c. An ability to function on multi-disciplinary teams & $80 \%$ & $69 \%$ \\
\hline g. A knowledge of contemporary issues & $71 \%$ & $55 \%$ \\
\hline $\begin{array}{l}\text { d. An understanding of professional and ethical } \\
\text { responsibility }\end{array}$ & $71 \%$ & $65 \%$ \\
\hline $\begin{array}{l}\text { h. An ability to use the techniques, skills, and modern } \\
\text { technology necessary for professional practice }\end{array}$ & $69 \%$ & $45 \%$ \\
\hline $\begin{array}{l}\text { i. An understanding of the national and international } \\
\text { aviation environment }\end{array}$ & $45 \%$ & $33 \%$ \\
\hline $\begin{array}{l}\text { a. An ability to apply knowledge of mathematics, } \\
\text { science, and applied sciences }\end{array}$ & $41 \%$ & $29 \%$ \\
\hline $\begin{array}{l}\text { f. A recognition of the need for, and an ability to } \\
\text { engage in, life-long learning }\end{array}$ & $37 \%$ & \\
\hline
\end{tabular}




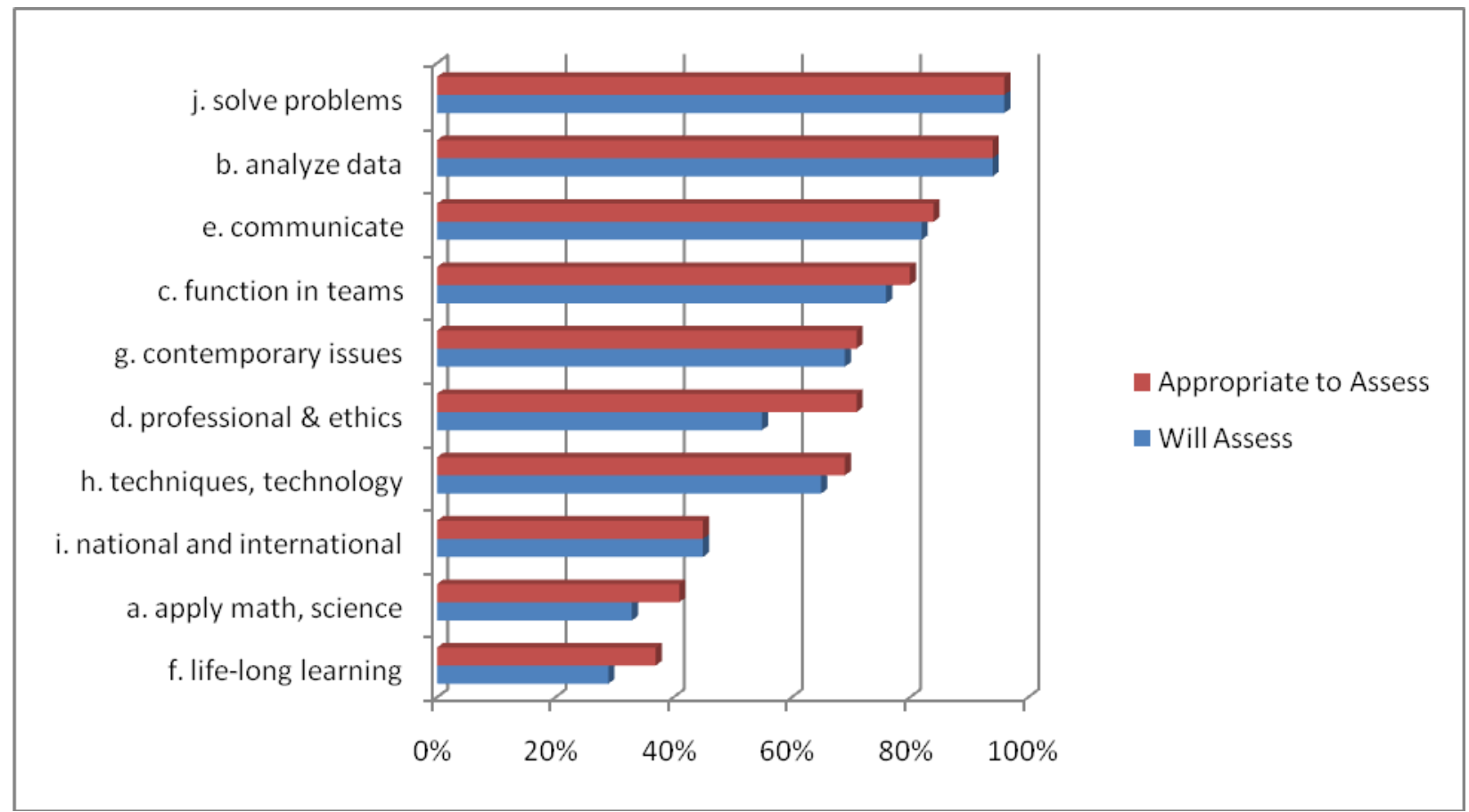

Figure 1. Outcomes in Graphical Form.

Further analysis was conducted to determine if there were any significant differences between general outcomes that the respondents felt were appropriate to assess, however were not planned on being assessed. A series of paired sample t-tests were performed between each paired variable. Only two variables were found to have a significant difference in the paired testing: d.) an understanding of professional and ethical responsibility and f.) recognition of the need for, and an ability to engage in, life-long learning.

The most significant difference occurred for the general outcome concerning professional and ethical considerations. While $71 \%$ of responders felt the outcome was appropriate to assess, only $55 \%$ stated that they plan to assess. This resulted in a $\mathrm{t}(55)=-3.050, \mathrm{p}=.004$. The other outcome regarding life-long learning had $37 \%$ of the responders stating they felt it appropriate to assess, however only $29 \%$ stated that they plan to assess that outcome in their culminating experience. This resulted in a $\mathrm{t}(55)$ $=-2.063, \mathrm{p}=.044$.

\section{DISCUSSIONS AND RECOMMENDATIONS}

Although the criteria of requiring a culminating experience are rather new to accredited aviation programs, the vast majority of accredited programs have already identified and/or created the experience in their curriculum. The programs surveyed all indicated the importance of this experience in their overall aviation education curricula. Aviation programs also appear to be tying the assessment activities of the culminating experience to specific AABI general outcomes. Of the 10 listed AABI general outcomes, schools plan to assess over six outcomes on average in their culminating experience.

However, the disparity between appropriateness to assess and planning to assess needs to be further evaluated. For instance, when evaluating the two variables mentioned in the previous section (professional/ethical considerations and life-long learning) two questions occur; why do significantly more programs feel that some outcomes are appropriate to assess yet have no plan to assess these outcomes in their culminating experience? If these goals are not assessed in the culminating experience, when will they be assessed? Lastly, 
aviation educators need to collectively determine and discuss what are some appropriate and effectives means of which to assess these less tangible general outcomes.

Prather (2008) found that the aviation industry as a whole is not fully aware of AABI or the role that it plays in accrediting aviation programs. Perhaps by following the lead taken by both business and engineering education, who closely tie their culminating experiences with industry support, aviation programs could benefit as well. It could prove to be the catalyst needed to achieve better industry recognition and awareness of collegiate aviation programs.

Further research needs to be conducted concerning culminating experiences in aviation education. A qualitative study consisting of interviews and document analysis of various capstone course syllabi would help facilitate an even more in-depth discussion on current practices and assessment techniques. Another area for further research would include the numerous non-accredited aviation programs to distinguish if any of them currently have, or plan to incorporate a defined culminating experience in their programs. Lastly, a similar follow-up survey needs to be conducted after all currently accredited programs complete their initial reaffirmation of accreditation under the new criteria. Aviation programs may use that process as a time of reflection to change their existing culminating experience to better assess the AABI general outcomes.

\section{CONCLUSION}

As aviation educational programs embark on this new path toward outcomes-based accreditation, careful thought and planning needs to be exercised in meeting the new criteria. Aviation programs should use this opportunity to create effective and worthwhile culminating experiences to not only meet the new requirements of $\mathrm{AABI}$ accreditation, but to improve the quality of the educational experience for its students. By participating in dialogues with other aviation educators, and determining best practices in the field, all aviation programs can add a new element to their curriculum in order to best prepare its students for a successful career in the aviation industry. 


\section{REFERENCES}

Aviation Accreditation Board International. (2008). Accreditation Criteria Manual, Form 201. Available from the AABI website, http://www.aabi.aero/forms.html

Dutson, A., Todd, R., Magleby, S. \& Sorenson, C. (1997). A review of literature on teaching engineering design through project-orientated capstone courses. Journal of Engineering Education, 86(1), 17-28.

Howe, S. \& Wilbarger, J. (2006). 2005 national survey of engineering capstone design courses. Proceedings of the American Society of Engineering Educators Annual Conference, Chicago, IL.

Jenkins, S. R., Pocock, J., Zuraski, P., Meade, R., Mitcherll, Z. \& Farrington, J. (2002). Capstone course in an integrated engineering curriculum. Journal of Professional Issues in Engineering Education and Practice, 128(2), 75-82.

McKenzie, L., Trvisan, M., Davis, D. \& Beyerlein, S. (2004). Capstone design courses and assessment: A national study. Proceedings of the American Society of Engineering Educators Annual Conference, Salt Lake City, UT.

Padmanabhan. G. \& Katti, D. (2002). Using community-based projects in civil engineering capstone courses. Journal of Professional Issues in Engineering Education and Practice, 128(1), 12-18.

Parente, D., Brown, R. \& Warner, A. (2005). Review sessions and results: Competency testing in the capstone business course. Journal of Instructional Psychology, 32(3), 233-243.

Payne, S., Whitfield, J. M. \& Flynn, J. (2002). Assessing business capstone course through a method based on the SOTL and the stakeholder process. Journal of Education for Business, 78(6), 69-74.

Payne, S., Flynn, J. \& Whitfield, J. M. (2008). Capstone business course assessment: Exploring student readiness perspectives. Journal of Education for Business, 83(1), 141-146.

Prather, C. D. (2008). Stakeholder perceptions of specialized accreditation by the Aviation Accreditation Board International: Part two - aviation students and industry employers. Colleigiate Aviation Review, 26(2), 69-77.

Todd, R., \& Magleby, S. (2005). Elements of a successful capstone course considering the needs of stakeholders. European Journal of Engineering Education, 30(2), 203-214. 


\section{APPENDIX}

\section{Culminating Experience Survey}

\section{Institution Demographics}

1. Name of Institution:

2. AABI Program Option:

3. Degree Title:

4. In what year did or will you have your first accreditation visit under the new AABI outcomes based criteria?

5. How many students are currently in this aviation program option?

\section{Culminating Experience Questions}

6. Does your program currently have a culminating experience defined as required per AABI Criteria 4.0? (Please circle)

$$
\square \text { Yes } \quad \square \text { No }
$$

If not, are you currently in the process of developing such an experience?

7. What best describes your program's culminating experience?

$$
\begin{aligned}
& \square \text { Capstone Course } \\
& \square \text { Internship } \\
& \square \text { Special Project } \\
& \square \text { Other (specify) }
\end{aligned}
$$

8. What is the duration of your culminating experience?

$\square 1$ semester $\square 2$ semesters $\square$ other (please specify)

9. How important do you feel this course is for your program? (circle a number)

$$
\begin{array}{lllll}
\text { Not Important } 1 & 2 & 3 & 4 & 5
\end{array} \text { Extremely Important }
$$

10. Which of the following AABI defined general outcomes do you consider appropriate to assess in the culminating experience? (Check all that apply)

$\square$ a. An ability to apply knowledge of mathematics, science, and applied sciences

$\square$ b. An ability to analyze and interpret data

$\square$ c. An ability to function on multi-disciplinary teams

$\square$ d. An understanding of professional and ethical responsibility

$\square$ e. An ability to communicate effectively, including both written and verbal communication skills

$\square$ f. A recognition of the need for, and an ability to engage in, life-long learning

$\square$ g. A knowledge of contemporary issues

$\square$ h. An ability to use the techniques, skills, and modern technology necessary for professional practice

$\square$ i. An understanding of the national and international aviation environment

$\square$ j. An ability to apply pertinent knowledge in identifying and solving problems. 
11. Which of the following AABI defined general outcomes do you or will you assess in the culminating experience? (Check all that apply)

$\square$ a. An ability to apply knowledge of mathematics, science, and applied sciences

$\square$ b. An ability to analyze and interpret data

$\square$ c. An ability to function on multi-disciplinary teams

$\square$ d. An understanding of professional and ethical responsibility

$\square$ e. An ability to communicate effectively, including both written and verbal communication skills

$\square$ f. A recognition of the need for, and an ability to engage in, life-long learning

$\square$ g. A knowledge of contemporary issues

$\square$ h. An ability to use the techniques, skills, and modern technology necessary for professional practice

$\square$ i. An understanding of the national and international aviation environment

$\square$ j. An ability to apply pertinent knowledge in identifying and solving problems.

12. What type of evidence/assignments do you use or expect to use to assess student learning during the culminating experience? (Check all that apply)

$\square$ Exams

$\square$ Individual Papers

$\square$ Group Projects

$\square$ Oral Presentations

$\square$ Other (specify)

13. Comments: 